\title{
DESIGN AND ANALYSIS OF AN INTEGRATED EXHAUST MANIFOLD
}

\section{WITH TURBOCHARGER FOR CONSIDERABLE REDUCTION}

\section{OF OVER HEATING OF BEARING SYSTEM}

\author{
NIVIN JOY \\ School of Mechanical Engineering, Sathyabama Institute of Science \& Technology \\ (Deemed to be University), Chennai,Tamil Nadu, India
}

\begin{abstract}
Presently in turbocharger, turbine housing and exhaust manifold are supplied as two separate components to the engine manufacturer. It was observed that the flow path in the exhaust manifold was improper and led to high temperature region in the turbine housing and bearing housing. Due to the high temperature region, burning issues were observed in practical conditions. To avoid high temperature region and turbocharger failure, a proposal was made to combine the exhaust manifold and turbine housing. 3D CAD models of the existing design and the proposed integrated design were modeled using Creo Parametric 2.0 software package. Computational Fluid Dynamics (CFD) simulations were conducted on existing design to determine the heat distribution in the manifold and turbine housing. Heat transfer CFD simulations were conducted on the integrated turbine housing to determine the modified heat distribution over the turbine housing and bearing housing. The exhaust flow path in the integrated manifold was optimized to reduce the stagnation region and pressure losses of exhaust gas flow. To verify the strength of the turbine housing at high temperatures, Thermal Mechanical Fatigue (TMF) simulations were conducted on the optimized design. Using the integrated turbine housing design, the weight and manufacturing cost can be reduced and also the turbocharger performance and durability can be improved.

KEYWORDS: Exhaust Manifold, Turbocharger \& Bearing
\end{abstract}

Received: Sep 18, 2017; Accepted: Oct 28, 2017; Published: Mar 12, 2018; Paper Id.: IJMPERDAPR201870

\section{INTRODUCTION}

In exhaust gas turbo charging, an amount of exhaust gas energy, which normally is let out as waste is utilized to run a turbine. The turbine shaft connected to a compressor draw combustion air inside which is compressed and then supplied to the engine. As there is more air supply, more fuel can be burnt by allowing the engine to develop high power. This increased air availability improves the overall combustion of fuel, which leads to lower fuel consumption and less emission. [1]

The usage of Turbochargers is mostly found in aircrafts, trains automobiles, equipment engines used in construction sites. Turbochargers have also found its place in automotive fuel cells as well. It has an important role to solve environmental problems in automobile industry with lesser fuel consumption and considerably less emission. [2, 3]. To better understand the technique of turbo charging, it is useful to be familiar with the internal combustion engines principles of operation. Nowadays most of the commercial diesel engines are 4 stroke engines controlled by inlet and exhaust valves. A full cycle of engine running consists of four strokes with two complete 
revolutions of the crankshaft.

The compressor of turbocharger draws in ambient air and compresses it, before it enters into the inlet manifold at increased pressure. This facilitates the entry of good amount of air into the cylinders in each inlet stroke. The power required to spin the centrifugal compressor is derived from the kinetic energy of the exhaust gases expelled from the engine.

\section{BEARING SYSTEM}

The turbocharger shaft and turbine wheel assembly rotate at speeds up to $285,000 \mathrm{rpm}$ and speed of turbocharger categorized, based on the bearing system rotor capability in each size of turbine wheel. Turbocharger life should correspond to that of the engine, which could be $100,000 \mathrm{~km}$ for a commercial vehicle. Only sleeve bearings specially designed for turbochargers can meet these high requirements at a reasonable cost. Apart from lubrication, the oil film in the bearing clearances also has a damping function, which largely contributes to the stability of the shaft and turbine wheel assembly. But, it is also interesting to note that studies have also been carried out to examine the application of gas foil bearings in turbochargers and studied the effects of their clearance. [4]. However, oil film bearings are widely accepted. The clearances play a major role in optimizing the damping characteristics and load carrying capacity. Researchers have studied about the stability of a turbocharger with respect to the values of bearing clearances. [5]. The effect of outer clearance with fixed inner clearance values was also investigated [6]. Hence, the lubricating oil thickness for the inner clearances is selected with respect to the bearing strength and the outer clearances are selected with respect to the bearing damping. The bearing clearances are mostly given only a few hundredths of a millimeter. Exhaustive study has been carried out about the importance and essentiality of the clearances. Clearance determination based on the measured response was developed and influences on the bearing stability were also studied. [7]. Many studies have been carried out about the impact of the clearance on the contact stresses [8] and also their impact on the rotor-stator collisions and related resonances and self-excited vibrations [9]. Interestingly, influence of joint clearances were also studied [10].

\section{AIM AND SCOPE OF THE PROJECT}

Before this project, it was found that the product bearing system was over heated due to exhaust flow hitting on turbine housing at the gas flow passage. The aim of this work is to reduce the over heat of bearing system with optimization of flow geometry ( Integrated manifold turbine housing in turbocharger) and reduction of unwanted mass of the turbine housing.

With improved facilities and opportunities in the ever-improving automotive field, there is an increased demand for turbochargers. In today's competitive scenario, it becomes all the more important to focus on processes with reduced variation and improved flexibility with better quality. Hence in this work, an attempt is made of combining the exhaust manifold with Turbine housing as a single part. This also reduces turbocharger weight, machining cycle time and assembling time, which improves productivity in addition to reduction in price and lead time. 
of Over Heating of Bearing System

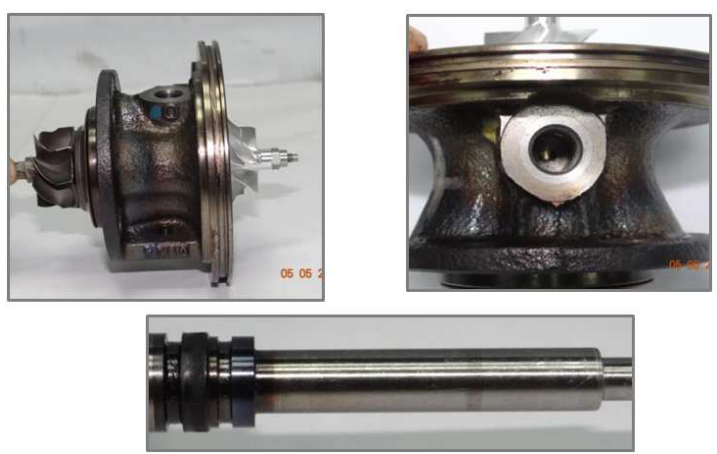

Figure 1: Overheated Bearing System

This Turbocharger was supplied to one of the leading passenger car manufacturing company for a small size engine. This Turbocharger is currently assembled with exhaust manifold and turbine housing as a separate component by fastening with bolt and nuts, and gasket is used to avoid the gas leakage from mating area of two components.

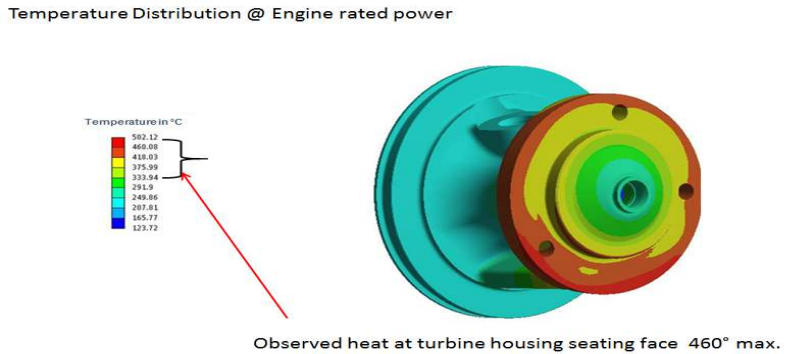

Figure 2: Bearing Housing Temperature Measurements

In this Turbine housing assembly, operator found it difficult to assemble exhaust manifold to turbine housing without fixture. This turbine housing assembly contains exhaust manifold, flap assembly and the lever assembly which control exhaust gas flow to turbine volute. This overall flap assembly is actuated by an actuator, which is mounted on compressor side and connected by control rod.

\section{DESIGN INSTRUCTIONS FOR GAS FLOW PATH}

In the example shown in the Figure 3 below, the channel position is designed symmetrically. It does not necessarily mean that the design is correct from a streaming point of view. The inset picture gives an explanation of the flow streamlines. The stream is not guided directly in the volute, but a part of the stream can be diverted into other direction.

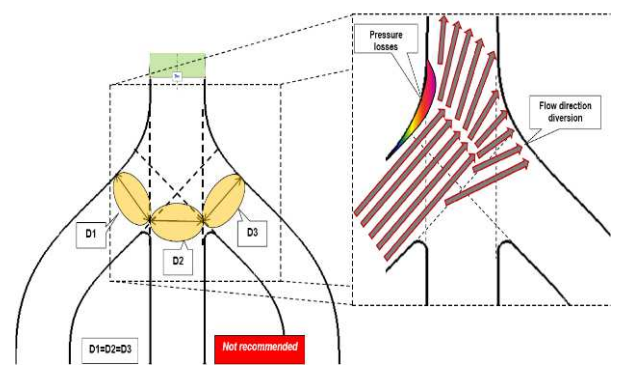

Figure 3: Gas Flow Path (Design Not Recommended) 


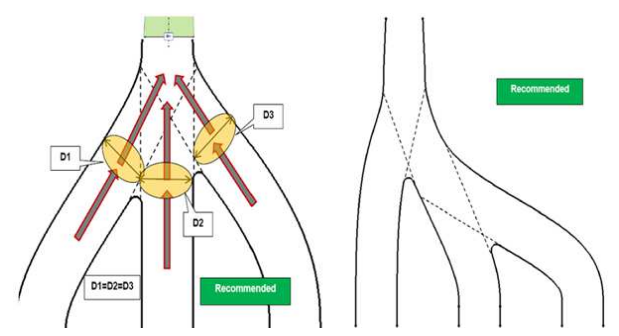

Figure 4. Gas Flow Path (Design Recommended)

Integrated design turbine housing will increase efficiency of turbine housing due to reduced friction loss, which induced in flange connection between turbine housing inlet flange to exhaust manifold outlet flange. The turbine housing volute and exhaust manifold gas flow surface is connected smoothly without any flow variation. This turbine housing volute is designed in Creo software in surface work bench by using boundary blend surface tool.

\section{CONVECTIVE HEAT TRANSFER CO-EFFICIENT (h)}

The $\mathrm{H}$ value should be applied on the surface of the turbine housing and exhaust manifold surface values are not same all over the turbine housing. It differs based on the cross section of the passage. For that, surfaces are divided like Zone-1, Zone-2, Zone-3, Zone-4, Zone-5 and Zone-6. Outer surface of the assembly is considered as natural convection. Different zones of the turbine housing are shown below.

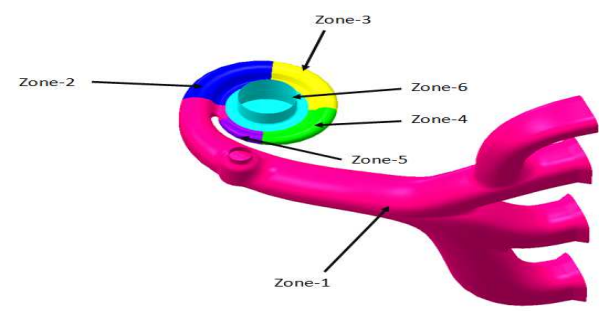

Figure 5: Division of Zones

\section{CALCULATION OF CONVECTIVE HEAT TRANSFER CO-EFFICIENT}

$\begin{array}{lll}\text { Gas Temperature } & = & 760^{\circ} \mathrm{C} \\ \text { Mass flow rate } & = & 0.16 \mathrm{Kg} / \mathrm{s}\end{array}$

\section{Properties of Gas at Inlet}

$\begin{array}{lll}\text { Density }(\rho) & = & 0.3258 \mathrm{Kg} / \mathrm{m}^{3} \\ \text { Specific pressure }(\mathrm{Cp}) & = & 1148 \mathrm{~J} / \mathrm{Kg} \mathrm{K} \\ \text { Thermal Conductivity }(\mathrm{k})= & 0.0687 \mathrm{~W} / \mathrm{m} \mathrm{K} \\ \text { Co-efficient of friction }(\mu)= & 4.270 * 10^{-5} \mathrm{Kg} / \mathrm{m}^{2} \\ \text { Prandtl Number (Pr) }= & 0.7175 \\ \text { Heat transfer Q } & =\quad\left(\mathrm{T}_{\text {in }}-\mathrm{T}_{\text {amb }}\right) /\left(\mathrm{R}_{\text {in }}+\mathrm{R}_{\text {mlt }}+\mathrm{R}_{\text {out }}\right) \\ \mathrm{T}_{\text {exit }} & = & \mathrm{T}_{\mathrm{s}}-\left(\mathrm{T}_{\mathrm{s}}-\mathrm{T}_{\text {in }} \mathrm{e}^{((-\mathrm{h} . \mathrm{A}) /(\mathrm{m} \cdot \mathrm{Cp}))}\right.\end{array}$

Similarly, we can calculate the convective heat transfer co-efficient for different zones of the turbine housing. 
Convective heat transfer co-efficient for different zones are given in the table below:

Table 1: Convective Heat Transfer Value for Different Zone

\begin{tabular}{|c|c|c|c|}
\hline \multirow{2}{*}{ SI No } & \multirow{2}{*}{ ZONE } & TEMPERATURE & $\mathbf{h}$ \\
\cline { 3 - 4 } & & ${ }^{\mathbf{0}} \mathbf{C}$ & $\mathbf{W} / \mathbf{m}^{\mathbf{2}} \mathbf{K}$ \\
\hline 1 & ZONE-1 & 760 & 408.18 \\
\hline 2 & ZONE-2 & 749 & 842.47 \\
\hline 3 & ZONE-3 & 748 & 924.36 \\
\hline 4 & ZONE-4 & 747 & 991.28 \\
\hline 5 & ZONE-5 & 745 & 1051.97 \\
\hline 6 & ZONE-6 & 634 & 1473.07 \\
\hline 7 & ZONE-7 & 634 & 289.12 \\
\hline
\end{tabular}

\section{THERMAL STRESS ANALYSIS}
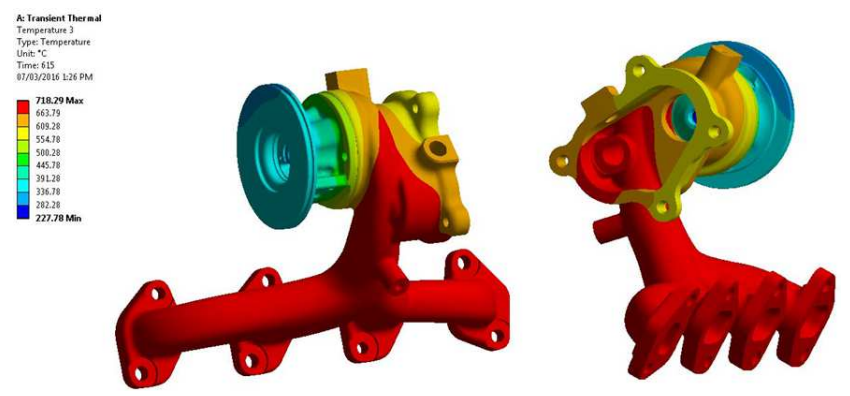

Figure 6: Thermal Stress Analysis

The thermal stress analysis is done for final design of turbine housing model, in which, modal analysis is done and frequency fall above $200 \mathrm{~Hz}$ in all three modes. The above figure shows temperature distribution in turbine housing when engine is in idling condition. In this condition, turbine housing can with stand temperature without any deformation in shape or geometry. As the engine is in idling condition, temperature will be minimum in turbine housing.
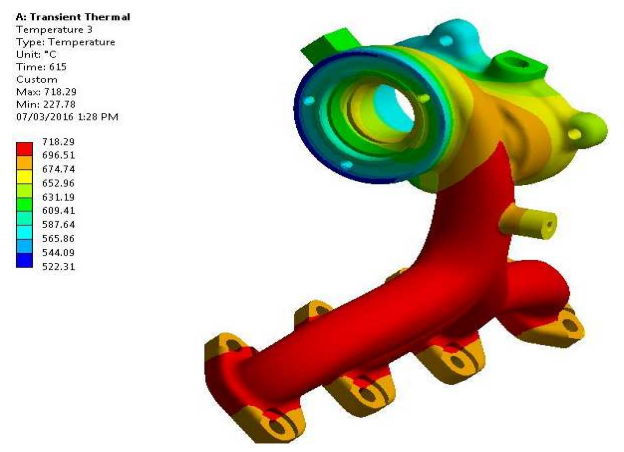

Figure 7: Thermal Stress Analysis for Final Design

The above Figure 7 shows the temperature distribution in turbine housing, when engine is in rated power condition. In this condition, turbine housing can with stand temperature without any deformation in shape or geometry. As the engine is in rated power condition, temperature will be maximum in turbine housing. As per analysis report, temperature will be high in inlet to volute connection area, approximately at $746^{\circ} \mathrm{C}$. Also, the temperature distribution was good, compared than existing design of two separate housing. 


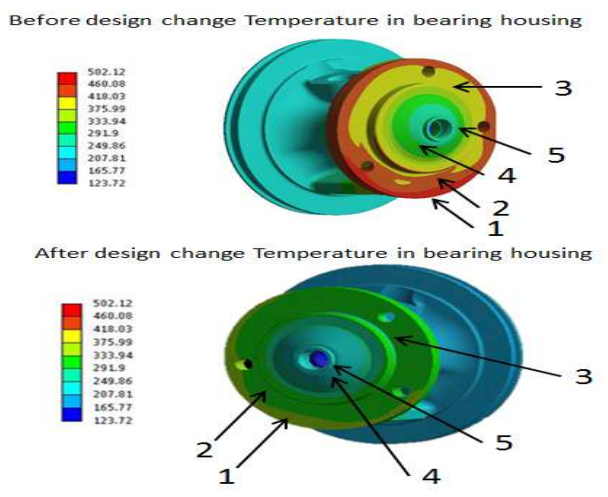

Figure 8: Thermal Stress Analysis (BHsg.)

Table 2: Temperature Differences Before and After Design Change

\begin{tabular}{|c|c|c|c|}
\hline $\begin{array}{c}\text { BHsg } \\
\text { Zone }\end{array}$ & $\begin{array}{c}\text { Before Design } \\
\text { Change }(\square \mathbf{C})\end{array}$ & $\begin{array}{c}\text { After Design } \\
\text { Change }(\square \mathbf{C})\end{array}$ & $\begin{array}{c}\text { Temperature } \\
\text { Difference }(\square \mathbf{C})\end{array}$ \\
\hline 1 & 502 & 418 & 84 \\
\hline 2 & 445 & 370 & 75 \\
\hline 3 & 400 & 330 & 70 \\
\hline 4 & 335 & 290 & 45 \\
\hline 5 & 260 & 245 & 15 \\
\hline \multicolumn{4}{|l}{ Temperature Difference Approx 84 max. } \\
\hline
\end{tabular}

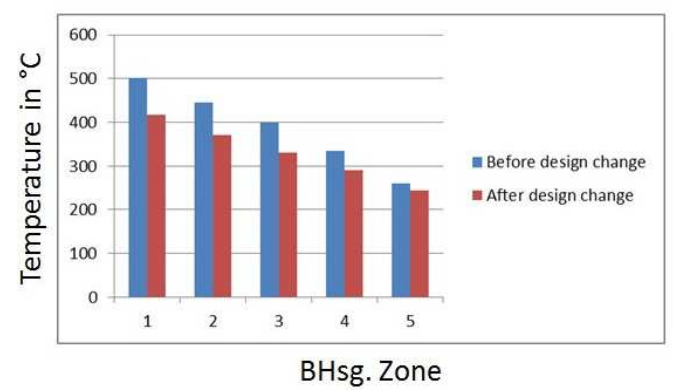

Figure 9: Comparison of Temperature Differences Before and After Design Change

The above Table 2 shows the temperature distribution in turbine housing and bearing housing, when engine is in rated power condition. In this condition, optimized turbine housing can be performed well in terms of flow and temperature distribution. Temperature of turbine housing and bearing housing has been measured from simulation.

The above Figure 9 shows a comparison graph of temperature differences recorded before and after the design change.

\section{SUMMARY AND CONCLUSIONS}

Hence, the final turbine housing design is done and validated in simulation software with modal and thermal stress analysis. The newly designed turbocharger housing increased overall efficiency (flow and temperature distribution) of turbocharger. Weight reduction of turbocharger housing reduce coast of component and also eliminate fastening component and gasket results, reduce the cost of turbocharger. By integrating exhaust manifold and turbocharger housing as single component, the tooling cost and transport cost are reduced. The result of temperature on bearing housing and turbine housing has been reduced approximately by $84 \square \mathrm{C}$. 
1. Romagnoli, A. Manivannan, S. Rajoo, M.S. Chiong, A. Feneley, A. Pesiridis, R.F. Martinez-Botas. 2017. "A review of heat transfer in turbochargers." Renewable and Sustainable Energy Reviews 79: 1442-1460

2. Leduc P, Dubar B, Ranini A, Monnier G. 2003. "Downsizing of gasoline engines: an efficient way to reduce CO2 emissions. " Oil Gas Sci Technol 58(1):115-127. Rev. IFP.

3. Silva C, Ross M, Farias T. 2009. "Analysis and simulation of low-cost strategies to reduce fuel consumption and emissions in conventional gasoline light-duty vehicles. ” Energy Convers Manage 50(2):215-222

4. Bhavinkumar N Patel \& Dattatraya Subhedar, Experimental and Numerical Investigation of Diesel Engine Turbocharger, International Journal of Automobile Engineering Research and Development (IJAuERD), Volume 6, Issue 3, May - June 2016, pp. 11-16

5. Sim K, Lee YB, Kim TH. 2013. "Effects of mechanical preload and bearing clearance on rotordynamic performance of lobed gas foil bearings for oil-free turbochargers.” Tribology Transactions 56:224-235.

6. Zhang H, Shi Z, Zhen D, Gu F, Ball A. 2012. "Stability analysis of a turbocharger rotor system supported on floating ring bearings. ” J Phys Conf Ser 364012032.

7. Tian L, Wang WJ, Peng ZJ. 2012. "Effects of bearing outer clearance on the dynamic behaviours of the full floating ring bearing supported turbocharger rotor.” Mech Syst Signal Process 31:155-175.

8. Papadopoulos CA, Nikolakopoulos PG, Gounaris GD. 2008. "Identification of clearances and stability analysis for a rotorjournal bearing system." Mech Mach Theory 43:411-426.

9. Rezaei A, Van Paepegem W, Ost W, De Baets P, Degrieck J. 2012. "A study on the effect of the clearance on the contact stresses and kinematics of polymeric composite journal bearings under reciprocating sliding conditions.” Tribol Int 48:8-14.

10. Ishida Y, Inagaki M, Ejima R, Hayashi A. 2009. "Nonlinear resonances and self-excited oscillations of a rotor caused by radial clearance and collision.” Nonlinear Dyn 57:593-605

11. Erkaya S, Dogan S, Ulus S. 2015. "Effects of joint clearance on the dynamics of a partly compliant mechanism: numerical and experimental studies.” Mech Mach Theory 88:125-140. 
